people's civilization out of the civilization of a privileged few. Great Britain in particular needs to grasp this relationship of reconstruction policy to the War effort, and to recognize that the vision of a new order at home and abroad is an indispensable weapon both in the waging of a war and in the winning of a peace.

\section{The United States and the War}

Writren before the United States entered the War "The Arsenal of Democracy" (Oxford Pamphlets on World Affairs, No. 53. London: Oxford University Press. 4d. net) still gives a pertinent account of the economic contribution of the United States towards the defeat of the Axis powers. After describing the movement of American opinion towards aid to Britain and her Allies, and the successive stages of American action before and after the passage of the Lease-Lend Act, Mr. A. J. Brown discusses the war-potential of the United States and its mobilization. His pamphlet gives a lucid account of the problems of the transfer of a peace-time economy to a war-footing and, if supplemented by current articles of the type appearing in recent issues of Fortune, should enable the reader to assess reasonably the significance of the bottlenecks of machine tools, skilled labour and raw materials. The labour and administrative problems are clearly displayed and the American contribution in shipbuilding, aircraft production and other supplies is fairly indicated; there is a useful appraisal of the relative strength of Great Britain, the United States and the U.S.S.R. in comparison with the Axis powers and with special reference to the time factor.

\section{Academy of Sciences of the U.S.S.R.}

A GENERAL meeting of members and corresponding members of the Soviet Academy of Sciences was held in Sverdlovsk, in the Urals, during May 2-7, to discuss the plan of scientific research work for 1942. The following papers were read: "Urgent Tasks of Science in Mobilizing the Resources of the Eastern Districts of the U.S.S.R. for the Needs of Defence", by Profs. Komarov and Bardin; "The Tasks of Social Science in the War", by Prof. Alexandrov; "Some Fundamental Problems of Agricultural Science", by Prof. Lyssenko; "Physics and the War", by Prof. Joffe; "Biology and War", by Prof. Orbeli ; "The Teutonic Order, its Early Successes and Final Defeat", by Prof. Tarle; "Historic Documents of the Red Patriotic War", by Minsky. The meeting also discussed the adjustment of the Academy's work in accordance with the needs of the War.

\section{Medical Progress in China}

In a recent lecture published in the Asiatic Review of April, Dr. W. H. Woo gives an interesting survey of medical progress in China from the earliest times. The origin of native medicine can be traced back to the earliest Chinese emperors, who flourished three or four thousand years ago. So early as the Chou dynasty, about 700 B.c., medicine had reached a high degree of development, and four kinds of medical man-physician, surgeon, dietician and veterinary surgeon-were distinguished. Afterwards, one of the most notable events in the history of Chinese medicine was the publication by $\mathrm{Li}$ Shee Chin about A.D. 1578 of a materia medica consisting of fifty-two volumes and containing not only herbs but also drugs of animal and mineral origin as well. A new medicine was introduced in 1835 , being due chiefly to Dr. Parker, who founded the first hospital in China, but it was not until three quarters of a century later that Sun Yat Sen, the founder of the Chinese Republic and himself a medical man, placed medical services on a proper footing.

In 1927 a Ministry of Health was founded in China to reorganize public health centres and reform medical education. In spite of an energetic campaign against disease, the death-rate from various causes in China is still very high. According to the latest annual statistics, the infantile mortality in China is 200 per thousand, and the maternal mortality 15 per 1,000 , as compared with 53 per 1,000 and 4 per 1,000 respectively in Great Britain, and tuberculosis kills 5 out of every 1,000 Chinese, while in Great Britain the proportion is ten times lower. An active campaign has been undertaken against opium smoking, and this evil would doubtless have been eradicated but for the Japanese, who encouraged the habit and distributed opium free in occupied territory. In pre-war days, medical schools in China numbered about thirty-six, but many of them have since suffered from depletion of staff and loss of laboratory equipment, to remedy which the present policy of the Ministry of Education is to confine medical education to centres in Free China.

\section{Gold Coast Timbers}

ALx over the Empire, wherever forests at all accessible exist, the same formula is heard expressed : "War-time conditions have brought about an increased demand for timber both locally and for export"; and the demands of the fighting forces are to a large extent responsible for this increased demand. On several occasions allusion has been made to this factor in Nature. There may occasionally be an asset to set against these often unsupervised extra fellings, one of which is mentioned in a publication of the Forestry Department of the Gold Coast entitled "Gold Coast Timbers" (Govt. Printers, Accra, 1941), issued under the name of the Chief Conservator of Forests, who had the assistance of officers of the Department in its compilation. As was the case during the War of 1914-18, especially in India and Burma, the great demands by the Army and, in the present War, largely increased demands for commercial war production, have necessitated a larger call on the tropical forests and the bringing into utilization of timbers for which there was no commercial demand in peace-time. As the author says of the Gold Coast, timber is required for many and varied purposes, and species formerly but little used have come into prominence.

It was in view of this extra demand that the present small monograph was prepared. It only purports to give a summary of existing information about some of the more important Gold Coast timbers, forty-four in number; other species in the forests not mentioned may prove as useful, it is said, in the future, even if not more useful, than some of those here dealt with. There are some 20,000 square miles of high forest and double that number of savannah forest. Some $1-1 \frac{1}{2}$ million acres of the high forest are classed as at present accessible. On the subject of distribution and frequency of species, enumeration surveys have been carried out to a certain degree, but it is emphasized that average figures only have been obtainable from them. This 
is, however, quite in keeping with the ordinary first attempts to obtain some knowledge of the stocking in the tropical forest. The suggested classification of durability and impregnation susceptibility appear to be somewhat clumsy and capable of simplification. A summary of the uses of local timbers is given. The little monograph should prove of use both to forest officer and timber buyer; and may even ensure some measure of control over the all too common unsupervised fellings in tropical forests, which have been taking place on an increased scale.

\section{The Imperial Forestry Institute}

In the seventeenth annual report, for 1940-41, of the Imperial Forestry Institute (Oxford, The Holywell Press, Ltd., 1941) it is stated that the year was the first under the new organization, one result of which is to amalgamate the Oxford School of Forestry with the Institute. The interruptions of leave and so forth naturally interfered with Colonial forest officers taking refresher courses at the Institute. As has been the case with other forestry schools, practical forestry courses had to be confined to Great Britain. The professor of forestry, Prof. H. G. Champion, was fortunate in being able to retain a certain staff at the Institute. As a consequence some degree of investigation and experimental research work was continued in sylviculture, mensuration and management, soil science (in which the valuable co-operation of Dr. M. C. Rayner of Bedford College, London, was afforded), tropical forest botany and fruit pathology.

\section{Economy of Tin in Bearings}

SINCE the change to Japanese control of the tinproducing regions in south-eastern Asia, the sources of about two-thirds of their supplies have been lost to the Allies. In an attempt to make this good, the Ministry of Supply has just issued a pamphlet on modifications recommended in bearing-metal practice. More than 2,000 tons of tin are used annually in Great Britain in bearing-metals, and the new suggestions, if loyally adopted, would, it is estimated, ensure a saving of 65 per cent, equal to the entire output of the Cornish mines last year. This pamphlet is available from the Non-Ferrous Metals Control, Grand Hotel, Rugby, or the Tin Research Institute, Fraser Road, Greenford, Middlesex. The white bearing-metals have been divided into four groups with $80-92,68-75,7-12$ and $0-5$ per cent of tin respectively. Alloys with 12-68 per cent of tin have very rightly been omitted entirely, as suitable alloys for practically any purpose can be found in the compositions still retained, modified, if necessary, by other additions. A long list of typical bearings is given with the class of alloy suitable for each. Alloys falling outside these groups may be used only with the approval of the Non-Ferrous Metals Control.

A further appreciable saving may be made by reducing the thickness of white metal linings, a practice which has been steadily growing for some years. As a result, especially in the automobile industry, it has been found that the thinner linings can often carry heavier loads with an increased factor of safety. Other suggestions for economy include careful segregation and collection of scrap, the use of steel bushes lined with bronze instead of solid bronze ones, and the substitution, for most purposes, of an alloy containing 85 copper, 5 tin, 5 lead, and 5 zinc for Admiralty gunmetal.

\section{The U.S. National Academy and Calendar Reform}

A PoLl of the U.S. National Academy of Sciences indicates a three-to-one preponderance of opinion in favour of a calendar reform which would 'even up' the lengths of the months, giving each twenty-six working days and having each month begin on a Sunday. The ballot was conducted by Prof. W. E. Castle, of the University of California, Berkeley. He received responses from 168 of them, or more than half the membership of the Academy. Of those answering, 76 per cent favoured the change, 10 per cent opposed, and 14 per cent were undecided. Of those who favoured the change, 58 per cent wanted it initiated in 1945 , which is the next year that begins on a Sunday ; 42 per cent were against this unless the War ends soon enough.

\section{Earthquakes in the Pacific}

The United States Coast and Geodetic Survey, in co-operation with Science Service and the Jesuit Seismological Association has found the epicentres of two recent earthquakes. The first, on March 1, 1942, took place at $9 \mathrm{~h} .52 \cdot 0 \mathrm{~m}$. U.T. The tentative epicentre, calculated from instrumental recordings at eight observatories, was latitude $13^{\circ} \mathrm{N}$., longitude $91^{\circ} \mathrm{W}$., which is in the Pacific Ocean, south of San José in Guatemala (Central America).

The second shock, on March 5, 1942, at $19 \mathrm{~h}$. $48 \cdot 2 \mathrm{~m}$. U.T., had its provisional epicentre at latitude $48^{\circ} \mathrm{S}$., longitude $98^{\circ} \mathrm{W}$., which is in the Pacific Ocean to the west of southern Chile. The focus of this latter shock is estimated to have been at a depth of some 250-300 km., so that it might be termed an 'intermediate' shock. Earthquake shocks have been known to occur down to depths of $700 \mathrm{~km}$. Both the above earthquakes occurred in regions known to be liable to earthquakes.

\section{Demographic Census of Rio de Janeiro}

The last census of Brazil showed that on September 1, 1940, Rio de Janeiro had 1,781,567 inhabitants (J.Amer. Med. Assoc., Feb. 14). The decline of births was illustrated by the fact that whereas in the period 1921-1930 the births numbered 344,921, in the period 1931-1940 only 321,976 births were registered, although there was an increase in the population. In the first period there were 248,964 deaths, and in the second period 274,233. This increase, however, was not in proportion to the growth of the population. In the same periods the marriages numbered 80,545 and 106,112 respectively, though there was a decrease in the birth-rate. The population of the capitals of the Brazilian States was $5,661,091$ in 1940 , or $13 \cdot 6$ per cent of the population of the whole country. In 1920 the figure was only $8 \cdot 6$ per cent of the whole nation.

\section{Institute of Fuel : Melchett Medallist}

The Melchett Medal for 1942 of the Institute of Fuel has been awarded to Dr. Arno Carl Fieldner, the head of the Technologic Branch of the Bureau of Mines, Washington, for outstanding work carried out by him and under his supervision in connexion with fuel. The Melchett Medal was founded in 1930 by the first Lord Melchett, and has been presented to seven Englishmen, one American, one Frenchman, and three Germans. 